\title{
Grappling with the Enduring Challenges of Consumption Complex Syndrome in Nigeria (A Survey of the Footwear Industry)
}

\author{
Gazie S.Okpara (Corresponding author) \\ Sabbatical Senior Lecturer, Business School \\ Ghana Institute of Management and Public Administration (GIMPA) \\ P.O. box AH 50, Achimota, Accra, Ghana \\ Tel: 233-24-700-6379 E-mail: gazieokpara@yahoo.com
}

\author{
Aham V. Anyanwu \\ Professor of Marketing, Faculty of Business Administration \\ Imo State University \\ P.M.B 2000, Owerri, Nigeria
}

Tel: 234-80-3328-1364Ｅ-mail: ahamefuleprof@yahoo.com

Received: May 17, 2011 Accepted: June 7, 2011 doi:10.5539/ijms.v3n3p122

\begin{abstract}
Colonial experience, buoyed by global media, brought in its wake, an attitudinal predisposition towards foreign culture and products, to the detriment of the domestic economy and identity. Besides the existing stream of relevant literature, this paper aims at a comparative attitude measurement, as well as exploring the underpinnings of sustained choice irrationality in favor of foreign-labeled products. Using experiments in the footwear industry, this study established the prevalence of a "Consumption Complex Syndrome (CCS)" - a state of consumer mind that consistently predisposes him to foreign-labeled products, even when the domestic ones are preferred in a Blind Brand Experiment. The concomitant policy, entrepreneurial imperatives and a reconstruction of the Consumer Behaviour model are considered.
\end{abstract}

Keywords: Consumption complex syndrome, Shoes, Attitude, Bakassi lines, Indigenous entrepreneurship

\section{Introduction}

The origin of footwear is vague. However, ancient Egypt is generally credited with its use (especially sandals) in 3700BC (World Book Encyclopedia, 2001). Egyptian wall paintings also lend credence to this, showing thong sandals with flat soles made of papyrus or leather. Various laced sandals, some with heel guards and thickened soles, were won in Mesopotamia, Crete and Greece. Akkadian Sculpture shows slippers with upturned toes, of the type also worn in Persia.

A late $16^{\text {th }}$ Century innovation introduced high heels for both sexes. This fashion was particularly popularized by Louis XIV of France, who wore them to boost his modest height (Encarta Encyclopedia, 2005). In the 18 $8^{\text {th }}$ Century, the soft boot was replaced by the stiff cowhide jackboot, held up by a metal frame (jack) and often cut away behind the knee. Foot soldiers wore cheaper ankle boots with side buttoned, canvas gaiters. During the Napoleonic Wars, officers and other gentlemen wore jackboots, including Wellington while male civilians wore narrow, flat, buckled pumps.

By the mid- $19^{\text {th }}$ Century, shoes began to be mass - produced in several factories, and thus became more widely available to the general public. Men wore laced or elastic-sided ankle boots. Women wore heeled shoes, low cut, laced or buttoned to the ankle. Canvas - topped, rubber-soled shoes (sneakers) were introduced for sports. Since the $20^{\text {th }}$ Century till date, emphasis on youth and informality influenced shoe design. Protection, aesthetics and status symbol are key functions of footwear today.

In Nigeria, however, documented accounts (Agbonifor et al. 1998; Nwokoye, 2000) debunked the popular notion that trade in goods and craft is an imported culture, which started with the advent of the Europeans. These 
accounts buttressed the vibrancy of production and trade by different local communities, in craftsmanship (such as bronze, brass and leatherwork), besides agriculture. This trade continued internally and externally (in the latter case, with the monopoly of guilds, social classes) up till 1860: a year before Lagos became a British colony (Ukwu, 1981).

The advent of the Europeans only shifted the emphasis of this traditional economy from "real sector" to trading (in European ware). This was particularly accentuated by the amalgamation of major British firms, to form the United African Company (later renamed Royal Niger Company) with the ulterior motive of fending off local (and foreign) competition in these and other products of interest (Agbonifor, et al. 1998).

Following local agitations and restiveness, the company's Charter was revoked in 1899 for its monopolistic tendencies, "which deprived the local inhabitants of the benefits of free trade, and the advantages of choice in a competitive market" (Agbonifor, et al. 1998).

The activities of this (and other) colonial companies marked a turning-point in the consumption mapping of Nigerians, as it exposed local inhabitants to more convenient; and affordable western products, to the detriment of the existing local ones. The oil boom and the Udoji Salary Awards of the 1970s, were the last straw on the domestic real sector, as conspicuous consumption erupted.

It is against this backdrop that successive governments, especially from the late 1980 s, commenced desperate measures to reverse the now dangerous trading economy, with a high consumption preference for foreign products. The major measures included the Structural Adjustment Program (1986), and the New Industrial Policy of Nigeria (1988). These, in turn, led to the establishment of several relevant agencies (Udeh, 1999) such as:

- The Raw Materials Research and Development Council (RMRDC)

- Industrial Training Fund (ITF)

- Industrial Development Coordinating Committee

- Standard Organization of Nigeria (SON)

- Federal Institute of Industrial Research, Oshodi (FIIRO)

- Project Development Agency, Enugu (PRODA), etc.

In spite of these, poor attitude to home made products/firms especially footwear, persisted (Udeh, 1999).

Furthermore, Bullion (2004) using 1985 as the base year, revealed that the highest Index of Manufacturing Production (IMP) for the footwear sub-sector in Nigeria peaked only in 1987 at 93.9 percents. From 1997 to 2004, it consistently hovered "in the red" between 49.9 percent and 44.3 percent.

A clearer picture of the menace of "foreignization" of consumption in the footwear industry was captured by the Federal Office of Statistics (FOS) export-import figures for the period 1999 to 2002 (see Table 1 in the Appendices)

The economy paralysis in the indigenous footwear (and other) sectors, apparently informed the extant import prohibitions in February 2004, vide Item 33 of the Revised Federal Ministry of Finance Circular (2005). Yet, available cumulative figures from Central Bank of Nigeria (CBN) since the 1980s released in 2004, as well as the Manufacturers Association of Nigeria (MAN) on capacity utilization, remain worrisome (Ugwu, 2005). And between 2002 and 2009, 1.9 million jobs were lost, and 834 domestic manufacturing firms closed, owing to imports, smuggling and generally poor infrastructure (Mike, 2011).

The rest of this study is organized in four sections of literature review, methodology, analysis and findings/conclusion.

\subsection{Statement of the Problem}

Following the exposure of Nigerians to foreign products, first by colonialism, and later by the wave of globalization and global media, Nigeria's penchant for all manner of foreign brands of products had remained a national worry.

Starting with the Structural Adjustment Program (SAP) in 1986 to date, government had shown marked desperation and frustration in battling against consumption - fuelled import - mania and smuggling, which costs Nigeria an estimated N750 billion annually (Adenekan, 2011). The market disdain for home-made shoes in particular, has clear far-reaching implications bordering on the incapacitation of local industries, job loss, weak 
revenue, pressure on the Naira and on the external reserves. Worse, it leads to a loss of national identity in the world market's product mapping.

Several years after the release of the "Prohibitions Lists" which included footwear, little evidence of its efficacy in import substitution is recorded, as a study (Frimpong, 2005) showed that import persisted, using the West African sub-region under the guise of the ECOWAS Protocol on Trade Liberalization Scheme. Furthermore, between January and March, 2005, different banned products (including footwear) of 3,185,689 metric tones were brought into Nigeria as against the 2,960,986 metric tones of imports of the corresponding period in 2004 (Fadeyi, 2005).

Against this backdrop, government's effort so far to boost the patronage of local brands of different categories of products seemed to have yielded minimal results (Adenekan, 2011; Eshalomi, 2011). Apart from the structural (intra-firm) and environmental rigidities constraining the production and marketing of local brands of footwear, price and quality (Obuzie, 2008) had always been bandied as the core reasons for the poor attitude to, and patronage of local brands.

Preliminary investigation however seemed to debunk this notion. First, the home-made shoes were cheaper than the foreign ones. Second, domestic shoes' quality was comparably high (sometimes higher, due to "tropicalised finishing"), since most of the inputs/components were equally imported (Obuzie, 2008).

Inherent limitations with these government measures in improving the attitude to and patronage of home-made shoes, lie in the fact that they seem to have failed in addressing one of the complexities of the consumers' mind bordering on what may be called the "Consumption Complex Syndrome".

\subsection{Objectives of the Study}

The main objective of this study is to explore the prevalence and perils of consumption complex syndrome in Nigeria, and its implications to domestic real sector management. Specifically, it intends to:

1. Identify the key attributes sought by consumers in shoes purchase, and the ranking of such attributes.

2. Measure the market attitude strength index toward home-made shoes.

3. Compare the attitude strength index above (No. 3) with that for foreign brands of shoes on the one hand, and with the ideal shoe's attitude strength, on the other.

4. Determine whether consumption complex plays a significant role in shoe purchase behavior.

5. Establish whether a typical Nigerian consumer can truly distinguish objectively between home-made and foreign brands of shoes, without the labels (a blind brand experiment).

6. Make relevant recommendations towards better attitude to, and patronage of indigenous enterprise in Nigeria.

\subsection{Research Hypotheses}

Working towards the above objectives, the following hypotheses are hereby formulated in their null structures:

$\mathrm{Ho}_{1}$ : There is no significant difference in the attitude strength between home-made and foreign shoes.

$\mathrm{Ho}_{2}$ : There is no significant difference in preference pattern between home-made shoes and foreign ones, in a blind brand experiment.

$\mathrm{Ho}_{3}$ : Consumption complex is not a significant determinant of shoes' brand choice.

\subsection{Significance of the Study}

Poor attitude to home-made products is a major source of worry to government (Nenadi, 2005) and indigenous entrepreneurship (Mike, 2011). A contribution to an attitudinal change in favor of domestic products would therefore be significant. Specifically, the indigenous industrial sector in Nigeria will consequently witness a renewed demand-driven vibrancy.

Again, government is expected to benefit immensely from this attitudinal change, as the emerging vibrancy in the indigenous real sector, would increase revenue generation via taxes. Pressures on domestic currency and the external reserves would also ease off.

Furthermore, employment and general standard of living of citizens will improve. Above all, consumers' mind will be disabused from the subconscious enslavement inherent in consumption complex, where mere labels of country-of-origin remain the extant measure of quality.

This study will also hopefully add to the existing stock of knowledge in the realms of consumer behavior. 


\subsection{Limitations and Assumptions}

This study is obviously limited by the fact that only the shoes industry in Aba, Nigeria is the central focus. The researchers are mindful of the fact that broadening its frontiers to include other consumer products, and states in Nigeria, would have made a more representative scope. This is however suggested for further studies.

Again, to minimize ambiguities, the following assumptions are made:

(1) Though there are differences in quality of home-made shoes meant for different target markets, we assume that only the top-quality home-made ones will be used in the comparison with foreign ones. This is because the foreign brands are known to be of high quality and international standard.

(2) A pro-foreign Nigerian consumer, who cannot differentiate home-made shoes from foreign ones in a blind brand experiment, has a consumption complex syndrome, all things being equal.

(3) Given that shoe components can be imported (as is the present practice), we assume that the resultant shoes are home-made so long as they are assembled, coupled and finished in Nigeria.

\section{Theoretical Constructs}

\subsection{Pro-Foreign Attitude: An Evolution}

Existing stream of literature on consumers disposition to foreign (or local) brands largely focused on the "country of origin effects," or COE, the earliest study of which is traceable to Schooler in 1965 (Peterson and Jolibert, 1995). Bilkey and Nes (1982) also published a vastly referenced article that affirmed that COE does influence buyers' perception.

In practical terms however, pro-foreign attitude and consumption is a product of colonial experience, exacerbated today by the impact of mass media and the internet (Okechuku and Onyemah, 1999).

Owing to its adverse impact on indigenous entrepreneurship and national economy, policies and programs are conceptualized and executed to grapple with it. Australia is credited with one such program in its "Buy Australian" campaigns from 1923 (Elliot and Cameron, 1994). This campaign had long been replicated in several countries, under various themes, but generally geared towards pride in one's country and products. They range from "Re-branding Nigeria," "Gifted by Nature," (Uganda), "Proudly South African," "Buy local" (Ghana) etc. (Nworah, 2006; Njoku, 2004; Opoku and Akorli, 2009).

\subsection{Concept and Prevalence of Consumption Complex Syndrome (CCS)}

Consumption Complex Syndrome (CCS) is a state of the consumer's mind, which predisposes him to favor and prefer foreign-labeled products, without a consistently justifiable reason for this.

CCS is usually perpetuated by "Made-In" labels that indicate its country of origin (Peterson and Jolibert, 1995), which may differ from its country of manufacture (Okechuku and Onyemah, 1999). These labels are mere extrinsic product cue (like price, brand name, warranty, etc) which have no direct bearing on product performance.

The prevalence of various manifestations of CCS is well documented. Studies in China (Sklair, 1994), Vietnam (Shultz, Pecotich and Le, 1994; Ger et al, 1993), Democratic Republic of Congo (Friedman, 1990), Zimbabwe (Burke, 1996; Dakin and Carter, 2010), Ghana (Opoku and Akorli, 2009), Mozambique (John and Brady, 2009), Ethiopia (Belk, 1988), Niger (Arnould, 1989) and Nigeria (Oyeniyi, 2009; Okechuku and Onyemah, 1999; Ekeng and Ewah, 2010; Shenge, 2010; Achumba, 1998; Njoku, 2004) are replete with evidence of this syndrome.

Beyond the merit of choice democratization inherent in CCS, its demerits ranging from fake labeling (Opoku and Akorli, 2009; Gilley, 1996), collapse of indigenous and domestic industry (Ugwu, 2005; Eshalomi, 2011, Mike, 2011), increased unemployment (Amaefule, 2011; Njoku, 2004; Okechukwu and Onyemah, 1999), loss of national identity (Nworah, 2006), pressure on the exchange rate, loss of government revenue owing to smuggling (Adenekan, 2011), to vulnerability of economy, are well documented.

\subsection{Theories of Country-Of-Origin Effects}

Several models offer explanations to the disposition of consumers to or against foreign products. They could be summed up as theories of:

a) Superiority: This suggests that consumers see non-local brands as a determinant of quality and brand desirability (Elliot and Cameron, 1994). This theory is reported to hold sway mostly in developing economies (Belk, 1988; Okechuku and Onyemah, 1999; Papadopoulos and Heslop, 1990). 
b) Ethnocentrism: This theory unearthed a psychological notion of pride in consumers, which leads them to prefer products and brands from their own country. (Sharma, et al, 1995; Nagashima, 1970; Lillis and Narayana, 1974; Bannister and Saunders, 1978; Toyne and Walters, 1989).

c) Affinity/Animosity: In situations where no domestic substitutes exist to permit ethnocentrism, Watson and Wright (2000) discovered that consumers resort to foreign products from countries with which they have a cultural affinity. On the other hand animosity against a country (historical, political, cultural and other factors) negate this preference (Riefler and Diamantopoulos, 2007; Keenam and Pokrywczynski, 2009; Bahaee and Pisani, 2009b).

d) Transition: Ger et al (1993) showed that non-utilitarian product attributes such as status display, are more important in developing countries where interpersonal relationships are of prime importance. Again, owing to economic transition, income disparities and status mobility are high, which find expression in the tendency to claim differential status, through the exotic brands one consumes. These brands are largely foreign (Batra et al, 2000; Kottak, 1990; Arnould, 1989).

e) Missing Link-Consumption Complex: Review of existing literature has little explanation for a situation where consumers have no objectively verifiable and consistent rationale for preferring foreign brands of products (irrespective of origin) to local ones. Consumption Complex Syndrome is put forth here to encapsulate this phenomenon.

\section{Methodology}

This study focused on the shoes industry in Aba, Nigeria, which is a major hub in the indigenous footwear subsector. With its "Bakassi lines" in the Ariaria International Market, Aba has the second highest concentration of members of the Footwear Group in the Manufacturers Association of Nigeria (MAN), and the largest members in the footwear informal sector (Obuzie, 2008).

Our research design is intended to:

1) Study a sample of shoes manufacturers in the domestic "Footwear (also called Bakassi) Lines" in the Ariaria International Market, Aba, Nigeria.

2) Study a sample of consumers/users of shoes in Aba.

3) Conduct a blind-brand experiment on various shoes' loyalty. Here, we manipulated branding (an independent variable) and monitored its effect on shoe choice (dependent variable).

The collection of primary data was through interviews (with the shoe manufacturers in Aba), questionnaires (on consumer-respondents) and blind brand experiments (on the same consumers). The specimen of the pretested questionnaire is attached in Appendix 5. The Blind Brand Experiment (BBE) examined the presence, or otherwise, of Consumption Complex Syndrome (CCS) in shoes patronage, in Aba, Nigeria. The respondents who had earlier accepted and filled the questionnaires were studied further, by asking them to pick out their preferred shoes from a collection of unbranded (i.e. brand-concealed) domestic and foreign ones. A pro-foreign respondent therefore, who decisively picked the right one (foreign brand) did not have the CCS. Otherwise, he or she did.

1750 shops/owners comprise the sprawling Umuehilegbu Industrial (Shoes) Market, popularly called the Bakassi Lines. This is broken down into 70 lines (or columns) of approximately 25 shops each (Obuzie, 2008).

In determining the sample size for the shoe manufacturers, the one-tenth rule (Ezejelue and Ogwo, 1990) was used. Therefore, 7 lines out of the 70 comprised our sample size. Again, approximately 3 shops per line were drawn, as each line had between 20 and 30 shops depending on size. Consequently, a total of 21 shops $(7 \times 3)$ constituted the sample size for the domestic shoes manufacturers in Aba, Nigeria. The 7 lines out of 70, and the 3 shops within each line of 20-30 shops were drawn, using simple random sampling (without replacement).

Furthermore, 200 consumer-respondents were sampled for the Blind Brand Experiment from Aba (comprising Aba North and Aba South municipal councils).

Besides being the hub of domestic footwear production in Nigeria, Aba is considered appropriate for the study because of its high social mobility. Residents in Aba alone are a mish-mash of indigenes of states outside Abia and Nigeria. Therefore, Aba is considered large and cosmopolitan enough in ethnic mix, to be a fair representation of the research interest. The sampling (50:50) is gender-disproportionate, given that there were more males than females in Aba, in the 2005 census. The disproportionateness however, is informed by the perceived higher fashion consciousness of females. Judgmental sampling was used in the selection of the respondents who automatically constituted the elements for the Blind Brand Experiment (BBE) too. 
Apart from descriptive tables and charts, hypotheses were tested using Linear Compensatory Attitude Models, Kolmogorov-Smirnov D-test and Chi-Square Test.

\section{Analysis}

Data analysis was split into five sections. While the first two focused on the respondents' demography and pattern of shoe purchase, sections 3, 4 and 5 analyzed the attitude measurement, manufacturers' interviews, and hypotheses respectively.

\subsection{Demography of Respondents}

The relevant demographic attributes of respondents are summarized in Table 2 (see Appendix 1).

\subsection{Shoes Patronage Characteristics}

The summary of the respondents' behavioral characteristics toward shoes is contained in Table 3(see Appendix 1).

\subsection{Attitudinal Strength Indices (for Home and Foreign Shoes)}

Calculated attitude strength score for shoes ranges from 0 to 400 (see Table 4 in Appendix 1). It increases when the attitude object is unfavorable, and vice versa.

Comparing the calculated attitude strength scores (for home and foreign shoes) along the $0-400$ continuum therefore, it was discovered that home shoes have an unfavorable attitude score (359/400), indicating poor ratings on most shoe attributes as against the foreign shoes' score (41/400). In other words, while the home made shoes are 90 percent away from the perfect Attitude points, the foreign shoes are only 10 percent short.

\subsection{Analysis of Manufacturers' Interviews}

The summary of the outcome of the twenty-one shoe manufacturers interviewed are highlighted here thus:

1) Commencement: Most of the shoe manufacturers commenced operations between 1980 and 1999, with majority of them established in 1984 alone.

2) Structure: Majority of these outfits were unincorporated and owner-managed, with business names largely coined from the personal names of the owners.

3) Staff Strength: Staff strength is low, ranging from zero to six.

4) Input Source: All inputs are sourced within the Ariaria International Market, especially the "Samek Line"

5) Input Origin: The shoe components and materials are imported, except gum. However domestic components such as lining, leather and soles also exist.

6) Daily Output/Sales: While the daily output ranges from 30 to 120 pairs of footwear, the daily range of sales is between 25 and 100 .

7) International Markets: Cameroun is the highest source of foreign clientele for these shoe-makers. This is followed by Ghana and Gabon, with a sprinkling of customers from Togo, Kenya and Cote D'Ivoire.

8) Production/Marketing: The industry's most worrisome production problem is high input costs. Manual and therefore all-night production worsens this. Again, low selling price and consumers' inferiority perception of home-made shoes, make marketing intractable.

9) Impact of Ban: Very few respondents acknowledged that the ban on imported shoes, positively affected their output and sales, as they were largely cynical about it, insisting that the foreign shoes were still being massively smuggled in. This even led to their peaceful demonstration recently.

\subsection{Test of Hypotheses}

The three hypotheses were tested here, using Chi-square and Kolmogorov-Smirnov Tests.

\section{Hypothesis I}

$\mathrm{Ho}_{1}$ : There is no significant difference in the Attitude strength between home-made and foreign Shoes.

Kolmogorov-Smirnov (D) test was utilized here.

The relevant Kolmogorov-Smirnov (D) value is 0.40 , with a critical value of 0.100 at 0.05 level of significance (see Appendix 3). 
Decision: Since the calculated D (0.40), exceeds the critical value $(0.10)$ at 0.05 level of significance, we therefore reject the null hypotheses. In other words, there is a significant difference in the attitude strength between home-made shoes, and the foreign brands. Research objectives \# 2 and \#3 are therefore justified.

\section{Hypothesis II}

$\mathrm{Ho}_{2}$ : There is no significant difference in preference pattern between home-made shoes and the foreign ones, in a Blind Brand Experiment.

Again, Kolmogorov-Smirnov (D) test was also used here (Appendix 3).

Decision: Since the calculated D (0.01) is less than the critical value (0.096), at 0.05 level of significance, we therefore accept the null hypothesis that there is no significant difference in preference pattern between home-made shoes and the foreign ones, in a Blind Brand Experiment.

In other words, the pro-foreign shoe lovers can hardly pick out the foreign brands in a BBE. The research's sixth objective is therefore justified.

\section{Hypothesis III}

Ho3: Consumption complex is not a significant determinant of shoes' brand choice.

Unlike in preceding tests, this hypothesis utilized only the responses of the pro-foreign consumers in the BBE. Chi-square was the tool of analysis here-(Appendix 4).

Chi-square $\left(x^{2}\right)$ calculated value is 15.37 , with a critical value of 5.99 at 0.05 level of significance, and 2 degree of freedom.

Decision: Since the calculated $X_{2}(15.37)$ exceeds the $X_{2}$ critical value (5.99), the null hypothesis is therefore rejected. In other words, consumption complex is a significant determinant of shoe brand choice. This addresses the research objective \#4.

\section{Discussion of Findings, Recommendations and Conclusion}

\subsection{Findings}

The outcome of the data analysis and test of hypotheses are highlighted hereunder.

1) Home-made shoes have zero preference in Aba, Nigeria, as approximately 92 percent of respondents prefer foreign brands, with the remaining 8 percent undecided. This corroborates the opinion of the domestic shoe manufacturers, who inexorably resort to fake foreign labeling.

2) Quality/durability is the foremost attribute sought in shoes. This post-purchase attribute is weighed in terms of tensile strength, tear strength, abrasion resistance, colorfastness, cracking and bursting strength.

3) Italy is the preferred country-of-origin for foreign shoes, in Aba, Nigeria. However, no significant brand loyalty exists as 67 percent of respondents will settle for any other foreign brand in the absence of Italian shoes.

4) Majority of respondents have two functional pairs of shoes. Of this segment, 82 percent are males, with females dominating in the "multiple shoe-ownership" (more than four pairs) category.

5) Shoes are largely purchased "not too regularly" (once in five months). Considering the outliers, while males buy "very rarely" (once in twelve months or more), females purchase "very regularly" (monthly).

6) 98 percent of respondents claimed they could distinguish foreign shoes from the home-mades. Only 32 percent however could make this distinction in a blind brand experiment. Therefore labels of origin rather than shoe attributes (quality, style, price etc) significantly influence patronage.

7) Most respondents (96 percent) opined that home-made shoes are poorly patronized on account of their quality and durability. However, interview with the manufacturers revealed that first-grade home-made shoes are even more durable than the imported ones as a result of the additional hardly-visible hand-made sewing that enhances domestic shoes' tear strength.

8) The Attitude Strength Indices (ASI) for both home and foreign shoes indicate that while the foreign shoes are 10 percent short of the perfect ASI, home-mades are merely 10 percent short of the worst.

9) In a Blind Brand Experiment (BBE), there is no significant difference in preference pattern between home and foreign shoes, in spite of the negative "Aba-Made" attitude to domestic shoes.

10) Consumption Complex plays a significant role in preference for foreign brands of shoes, as respondents increasingly prefer the domestic ones in a BBE. 
11) High input cost and low selling price are respectively the major production and marketing problems facing domestic shoes producers. The input costs coupled with manual production restrict output to between 30 and 120 pairs per day. The imported cheaper shoes (especially from China), keep domestic prices at the barest minimum.

12) Every shoe component is officially importable, except gum. This makes domestic shoes almost an exact replica in quality and style as the popular imported ones.

\subsection{Recommendations/Conclusion}

Consequent on the findings, and as a step towards grappling with the stereotypical poor attitude to and patronage of home-made shoes, the following are recommended.

1) The use of foreign labels on home-made shoes should be legislated against, for what it implies: loss of national pride and identity, as well as negative stereotypical perpetuation. However, more thought should be given to partnering arrangements between local and foreign investors, so as to derive "the benefits of both worlds."

2) Government should sponsor a pan-Nigeria conduct of the Blind Brand Experiment on home and foreign shoes, as a credible way to "mindful consumption" (Sheth et al, 2011). It will also hopefully convince Nigerians on the remarkable improvements in quality of today "Aba-Made" shoes which are falsely labeled as and mistaken for foreign ones. It is believed that these experiments across states would be more credible than mere mass-media "Buy-local" campaigns.

3) The Standard Organization of Nigeria (SON) is challenged to be more vibrant in setting and actually maintaining standards, even in shoes. A corresponding mark of quality might be a domestic shoe-maker's unique selling point, and a consumer's search cue.

4) Government should make the ban on foreign shoes more effective so as to reflect its desired impact on the domestic real sector.

5) A revisit of the hitherto simple black-box model of buyer behavior in Marketing theory is recommended, to encapsulate the idiosyncratic Consumption Complex Syndrome (CCS) prevalent in attitudinal/purchase dispositions. A proposed model therefore is depicted and explained in Appendix 6.

6) Given that Consumption Complex Syndrome (CCS) was prevalent in shoes' purchase decision in Aba, it is recommended that further BBE studies be conducted in other regions in Nigeria. The essence would be to ascertain the extent of spread of this syndrome among the major ethnic/religious blocs.

\section{References}

Achumba, I. C. (1998). The Challenges of Service Marketing and Human Resource Development. Journal of Business, University of Lagos, 1(2).

Adenekan, Sulaiman (2011). How Smuggling is Crippling Nigeria's Economy - Investigation. The PUNCH Newspapers, February 25.

Agbonifoh, B. A, Ogwo, O. E., and Nnolim, D. A. (1998). Marketing in Nigeria: Concept, Principles and Decisions, Aba: Afritowers Ltd..

Amaefule, Everest. (2011). Nigeria Lost 1.9 million Manufacturing Jobs - MAN. The PUNCH Newspapers [Online] Available: www.punchontheweb.com/Artice.aspx?theartic=Art20110217445762 (February 17, 2011).

Arnould, Eric J. (1989). Toward a Broadened Theory of Preference Formation and the Diffusion of Innovation: Cases From Zinder Province, Niger Republic. Journal of Consumer Research, 16, September.

Bahaee, M., and Pisani, M. (2009b). Iranian Consumer Animosity and U.S. Products: A Witch's Brew or Elixir? International Business Review, 18(2).

Bannister, J. P., and Saunders, J. A. (1978). U.K Consumers' Attitudes Toward Import: The Measurement of National Stereotype Image. European Journal of Marketing, 2(8).

Batra, Rajeer, Ramaswamy, Venkatram, Alden, Dana L., Steenkamp, Jan-Benedict E. M., and Ramachander, S. (2000). Effects of Brand Local and Non-Local Origin on Consumer Attitudes in Development Countries, Journal of Consumer Psychology, 9(2).

Belk, R. W. (1988). "Third World Consumer Culture" in E. Kumcu and A. F. Firats (eds.). Research in Marketing: Marketing and Development - Toward Broader Dimensions.. Greenwich, CT: JAI. 
Billey, Warren, J., and Erik, Nes (1982). Country-of-Origin Effects on Product Evaluations. Journal of International Business Studies, 13(1).

Bullion (2004). A Central Bank of Nigeria Publication, 15, December.

Burke, T. (1996). Lifebuoy Men, Lux Women, Durham, Duke University Press.

Chisnall, Peter M. (1975). Marketing: A Behavioral Analysis, Berkshire. McGraw-Hill Book Company (UK) Ltd.

Churchill, Gilbert A. (1976). Marketing Research: Methodological Foundations, Illinois, The Dryden Press.

Dakin, John, A., and Carter, Steve (2010). Negative Image: Developing Countries and Country-of-Origin - An Example from Zimbabwe. International Journal of Economic and Business Research, 2(3-4).

Ekeng, Alex, B., and Ewah, Sunday, O. E. (2010). Analysis of Consumer Propensity Towards Foreign Products:

A Survey of Consumers in Two States in Nigeria. [Online] Available: www.papeers.ssrn.com/so/3/papers.cfm?abstract_id $=1607817$ ( March 1, 2011).

Elliot, Gregory, R., and Cameron, Ross, C. (1994). Consumer Perception of Product Quality and the Country-of-Origin Effect, Journal of International Marketing, American Marketing Association (2).

Encarta Encyclopedia [Online] Available: http://en.wikipedia.org/wiki/Encarta, (March 1, 2011).

Eshalomi, Mathew (2010). "Vegetable Oil: How Importation, Smuggling Threaten Local Market," in Ronke Badamus. The PUNCH Newspapers, February 25.

Friedman, J. (1990). Being in the World: Globalization and Localization. Theory, Culture and Society, 17.

Frimpong, Kwadwo (2005). Why Nigeria's Ban of Ghana Exports was Illegal. Homepage Ghana, November 10.

Ger, G., Belk, R. W., and Lascu, D. N. (1993). The Development of Consumer Desire in Marketing and Developing Economies: The Cases of Romania and Turkey. Advances in Consumer Research, L. McAlister and M.L. Rothschild (eds.). Provo, UT, Association for Consumer Research, 20.

Hawkins, Del I., Best, Roger J., and Coney, Kenneth A. (2001). Consumer Behavior: Building Marketing Strategy, $8^{\text {th }}$ ed. Boston, Irwin/McGraw-Hill Company.

John, Anna V. S., and Brady, Malcolm P. (2009). The Impact of Consumer Ethnocentrism Tendencies on Buyers Evaluation of the Quality of South African Packaged and Non-Packaged Consumables in Mozambique. International Journal of Business Research, International Academy of Business and Economics, 9(3) May.

Keenan, K., and Pokrywczynski, J. (2009). Country and Region of Origin as Advertising Copy-Points: Perceptions of Asia and Asian Nations in the Arab and Western Worlds. Paper Presented to the American Academy of Advertising, Asia Pacific Conference, Beijing, China, May.

Kottak, C. P. (1990). Prime Time Society. Belmont, CA, Wadsworth.

Lillis, C. M., and Narayana, C. L. (1974). Analysis of 'Made-In' Product Images - An Exploratory Study. Journal of International Business Studies, 5(2), Spring.

Mike, Jide (2011). Challenges and Opportunities of Manufacturing Investments in Nigeria. Paper Presented at the $10^{\text {th }}$ Biennial Techno-Exposition, organized by the Raw Materials Research and Development Council (RMRDC), in Abuja, 16 February.

Nagashima, A. (1970). A Comparison of Japanese and US Attitudes Toward Foreign Products. Journal of Marketing, 34, January.

Nenadi, Usman (2005). cited by Johnmark Ukoko, Ban on Imports: Impact on Manufacturing Sector. Business Times, June $20-26$.

Njoku, Uju, A. A. (2004). Marketability of Nigerian Textile Materials. A PhD Thesis in Marketing Management, St. Clements University, British West Indies.

Nwokoye, Nonyelu G. (2000). Modern Marketing for Nigeria: Principles and Practice, $2^{\text {nd }}$ ed. Onitsha: Africana-FEP Publishers Ltd.

Nworah, Uche (2006). Re-Branding Nigeria: Critical Perspectives on the Heart of Africa Image Project. [Online] Available: http://citeseerx.ist.psu.edu/viewdoc/download?doc=10.1.1.110 (March 1, 2011).

Obuzie, Eric (2008). Interview with the Chairman, Umuehilegbu Industrial Market (the Bakassi Lines), Ariaria.

International Market. Aba, Nigeria. 
Okechkukwu, Chike, and Onyemah, Vincent (1999). Nigerian Consumer Attitudes toward Foreign and Domestic Products. Journal of International Business Studies, 30(3), September.

Opoku, Robert, A., and Akorli, Patrick, A. K. (2009). The Preference Gap: Ghanaian Consumers' Attitudes toward Local and Imported Products. African Journal of Business Management, 3(8), August.

Oyeniyi, Omotayo (2009). Analysis of Nigerian Consumers' Perception of Foreign Products. [Online] Available: www-upg-bulletin-serro/achieve/2009-3/3-220Oyeniyi-pdf (March 1, 2011).

Papadopoulos, Nicolas, and Heslop, Louse, A. (1990). A Comparative Image Analysis of Domestic VersusImported Products. International Journal of Research in Marketing, 7(4).

Peterson, Robert, A., and Jolibert, Alain, J. P. (1995). A Meta-Analysis of Country-of-Origin Effects. Journal of International Business Studies, 26(4), $4^{\text {th }}$ Quarter.

Riefler, P., and Diamantopoulos, A. (2007). Consumer Animosity: A Literature Review and a Reconsideration Of Its Measurement. International Marketing Review, 34(1).

Sharma, S., Shimp, T., and Shin, J. (1995). Consumer Ethnocentrism: A Test of Antecedent and Moderators. Journal of the Academy of Marketing Science, 23(1).

Shenge, Nyitor A. (2010). Impact of Country of Origin and Price on Products' Advertisement Efficacy. Journal of Social Science, 24(3).

Sheth, Jagdish, N., Sethia, Nirmal, K., and Srinivab, Shanthi (2011). Mindful Consumption: A Customer-Centric Approach to Sustainability. Journal of the Academy of Marketing Science, 39(1).

Shultz, C. J., Pecotich, A., and Le, K. (1994). Changes in Marketing Activities and Consumption - the Socialist Republic of Vietnam. cited in "Effects of Brand Local and Non- Local Origin on Consumer Attitudes in Developing Countries," Rajeer Batra, Venkatram Ramaswamy, Dana L. Alden, Jan-Benedict E.M. Steenkamp and S. Ramachander (2000), Journal of Consumer Psychology, 9(2).

Sklair, L. (1994). The Culture-Ideology of Consumerism in Urban China: Some Findings in a Survey in Shanghai. cited in "Effects of Brand Local and Non-Local Origin on consumer Attitudes in Developing Countries," Rajeer, Batra, Venkatram Ramaswamy, Dana L. Alden, Jan-Benedict E.M. Steenkamp and S. Ramachander (2000). Journal of Consumer Psychology, 9(2).

Toyne, B., and Walters, P. (1989). Global Marketing Management: Strategic Perspective. Boston: Allyn and Bacon.

Udeh, John, O. (1999). Entrepreneurship in the $21^{\text {st }}$ Century, Enugu: Catholic Institute for Development, Justice and Peace.

Ugwu, Charles (2005). Manufacturers Groan Under Harsh Polices. Business Times, 30 December - 2 January.

Ukwu, Ukwu, I. (1981). Trade and Marketing in Traditional Nigerian Society. Nigerian Journal of Development Studies, 1, April 19.

Watson, John J., and Wright, Katrina (2000). Consumer Ethnocentrism and Attitudes toward Domestic and Foreign Products. European Journal of Marketing, 34(9 \& 10).

Wilkie, William, L., and Pessemier, Edgar A. (1973). Issues in Marketing's Use of Multi-Attribute Attitude Models. Journal of Marketing Research, 10(4), November.

World Book Encyclopaedia (2001). Volume 17, Chicago: World Book Inc.

Zimbardo, P. G., Ebbesen, E. B., and Maslasch, C. (1977). Influencing Attitudes and Changing Behaviour, $2^{\text {nd }}$ ed. Massachusetts: Addison-Wesley Inc. 


\section{Appendix 1 In-text Analytical Tables}

Table 1. Export and Import Figures for Footwear in Nigeria, 1999-2002

\begin{tabular}{|l|l|l|l|l|l|}
\hline \multirow{4}{*}{ Exports } & Value (FOB, Nm) & 1999 & 2000 & 2001 & 2002 \\
\cline { 3 - 6 } & & 57.7 & 14.6 & 14.6 & 47.7 \\
\cline { 2 - 6 } & Percentage & 0.0 & 0.0 & 0.0 & 0.0 \\
\hline \multirow{2}{*}{ Imports } & Value (CIF, Nm) & 951.3 & $1,394.9$ & $1,538.9$ & $2,728.7$ \\
\cline { 2 - 6 } & Percentage & 0.2 & 0.2 & 0.2 & 0.2 \\
\hline
\end{tabular}

Source: FOS, Nigeria 2004

Table 2. Demographic Profile of Respondents

\begin{tabular}{|c|c|c|c|c|}
\hline $\mathrm{S} / \mathrm{N}$ & Variable & Option & Frequency & $\%$ \\
\hline 1 & Age Bracket & $\begin{array}{l}18-24 \\
25-31 \\
32-38 \\
39-45 \\
46+\end{array}$ & $\begin{array}{l}26 \\
82 \\
27 \\
44 \\
21\end{array}$ & $\begin{array}{l}13 \\
41 \\
13.5 \\
22 \\
10.5\end{array}$ \\
\hline & Total & & 200 & 100 \\
\hline 2 & Occupation & $\begin{array}{l}\text { Applicants/Students } \\
\text { Artisans } \\
\text { Civil servants } \\
\text { Business persons } \\
\text { Professionals (Pte Sector) } \\
\text { Politicians }\end{array}$ & $\begin{array}{l}98 \\
10 \\
35 \\
28 \\
21 \\
8\end{array}$ & $\begin{array}{l}49 \\
5 \\
17.5 \\
14 \\
10.5 \\
4\end{array}$ \\
\hline & Total & & 200 & 100 \\
\hline 3 & Education & $\begin{array}{l}\text { None } \\
\text { Primary } \\
\text { Secondary } \\
\text { Diploma/post secondary } \\
\text { Firs degree } \\
\text { Post-graduate } \\
\end{array}$ & $\begin{array}{l}0 \\
6 \\
48 \\
36 \\
89 \\
18\end{array}$ & $\begin{array}{l}0 \\
3 \\
24.4 \\
18.3 \\
45.2 \\
9.1\end{array}$ \\
\hline & Total & & 197 & 100 \\
\hline 4 & Income & $\begin{array}{l}\text { Less than N6000 } \\
\text { N6001 - N20000 } \\
\text { N20001 - N35000 } \\
\text { N35001 - N } 60000 \\
\text { N60001 - N90000 } \\
\text { N90001 + }\end{array}$ & $\begin{array}{l}47 \\
62 \\
43 \\
21 \\
18 \\
9\end{array}$ & $\begin{array}{l}23.5 \\
31 \\
21.5 \\
10.5 \\
9 \\
4.5\end{array}$ \\
\hline 5 & Marital Status & $\begin{array}{l}\text { Single } \\
\text { Married } \\
\text { Separated /divorced }\end{array}$ & $\begin{array}{l}116 \\
68 \\
12\end{array}$ & $\begin{array}{l}58 \\
35.5 \\
6.5\end{array}$ \\
\hline & Total & & $196^{*}$ & 100 \\
\hline
\end{tabular}

*3 respondents did not respond to the question about Education. 
Table 3. Patronage Pattern for Shoes

\begin{tabular}{|c|c|c|c|c|}
\hline $\mathrm{S} / \mathrm{N}$ & Variable & Option & Frequency & $\%$ \\
\hline 1 & $\begin{array}{l}\text { Nature of Shoe } \\
\text { Preference }\end{array}$ & $\begin{array}{l}\text { Home-made } \\
\text { Foreign-made } \\
\text { Anyone }\end{array}$ & $\begin{array}{l}0 \\
183 \\
17\end{array}$ & $\begin{array}{l}0 \\
91.5 \\
8.5\end{array}$ \\
\hline & Total & & 200 & 100 \\
\hline 2 & $\begin{array}{ll}\text { Reason } & \text { for } \\
\text { Shoe-type } & \\
\text { Preference } & \end{array}$ & $\begin{array}{l}\text { Quality } \\
\text { Durability } \\
\text { Elegance } \\
\text { No direct opinion }\end{array}$ & $\begin{array}{l}68 \\
72 \\
23 \\
20\end{array}$ & $\begin{array}{l}37 \\
39 \\
13 \\
11\end{array}$ \\
\hline & Total & & $183^{*}$ & 100 \\
\hline 3 & $\begin{array}{l}\text { Preferred Country } \\
\text { of Origin }\end{array}$ & $\begin{array}{l}\text { Italy } \\
\text { Spain } \\
\text { UK } \\
\text { Others** }\end{array}$ & $\begin{array}{l}133 \\
41 \\
16 \\
10\end{array}$ & $\begin{array}{l}66.5 \\
20.5 \\
8 \\
5\end{array}$ \\
\hline & Total & & 200 & 100 \\
\hline 4 & $\begin{array}{lr}\text { Degree } & \text { of } \\
\text { Ownership } & \text { (in } \\
\text { Pairs) } & \end{array}$ & $\begin{array}{l}\text { One } \\
\text { Two } \\
\text { Three } \\
\text { Four } \\
\text { More than four }\end{array}$ & $\begin{array}{l}9(6 \mathrm{M}, 3 \mathrm{~F}) \\
82(67 \mathrm{M}, 15 \mathrm{~F}) \\
51(20 \mathrm{M}, 31 \mathrm{~F}) \\
30(5 \mathrm{M}, 25 \mathrm{~F}) \\
28(2 \mathrm{M}, 26 \mathrm{~F})\end{array}$ & $\begin{array}{l}4.5 \\
41 \\
25.5 \\
15 \\
14\end{array}$ \\
\hline & Total & & 200 & 100 \\
\hline 5 & $\begin{array}{l}\text { Frequency of Shoe } \\
\text { Purchase }\end{array}$ & $\begin{array}{l}\text { Very Regularly (Monthly) } \\
\text { Regularly (3-Monthly) } \\
\text { Not too Regularly (5-Monthly) } \\
\text { Rarely (8-Monthly) } \\
\text { Very Rarely (At least annually) }\end{array}$ & $\begin{array}{l}16(0 \mathrm{M}, 16 \mathrm{~F}) \\
25(2 \mathrm{M}, 23 \mathrm{~F}) \\
61(15 \mathrm{M}, 46 \mathrm{~F}) \\
40(32 \mathrm{M}, 8 \mathrm{~F}) \\
58(51 \mathrm{M}, 7 \mathrm{~F})\end{array}$ & $\begin{array}{l}8 \\
12.5 \\
30.5 \\
20 \\
29\end{array}$ \\
\hline & Total & & 200 & 100 \\
\hline 6 & $\begin{array}{ll}\text { Shoe } & \text { Distinction } \\
\text { Ability } & \end{array}$ & $\begin{array}{l}\text { Yes } \\
\text { No } \\
\text { Sometimes }\end{array}$ & $\begin{array}{l}195 \\
0 \\
4 \\
\end{array}$ & $\begin{array}{l}98 \\
- \\
2 \\
\end{array}$ \\
\hline & Total & & 199 & 100 \\
\hline 7 & $\begin{array}{l}\text { Shoe Distinguishing } \\
\text { Attributes }\end{array}$ & $\begin{array}{l}\text { Label of Origin } \\
\text { Packaging } \\
\text { Price } \\
\text { Finishing /sleekness } \\
\text { Leather } \\
\text { Durability (Quality) } \\
\text { Others }\end{array}$ & $\begin{array}{l}21 \\
20 \\
19 \\
12 \\
48 \\
61 \\
8 \\
\end{array}$ & $\begin{array}{l}11.1 \\
10.6 \\
10 \\
6.3 \\
25.4 \\
32.3 \\
4.2 \\
\end{array}$ \\
\hline & Total & Option & $189 * * *$ & 100 \\
\hline 8 & $\begin{array}{l}\text { Preferred } \quad \text { Shoe } \\
\text { Attributes }\end{array}$ & $\begin{array}{l}\text { Price } \\
\text { Style /Design } \\
\text { Quality/Durability } \\
\text { Packaging } \\
\text { Comfort } \\
\text { Finishing } \\
\text { Availability }\end{array}$ & $\begin{array}{l}11 \\
37 \\
108 \\
15 \\
19 \\
5 \\
3\end{array}$ & $\begin{array}{l}5.6 \\
18.7 \\
54.5 \\
7.6 \\
9.6 \\
2.5 \\
1.5\end{array}$ \\
\hline & Total & & $198 * * * *$ & 100 \\
\hline 9 & $\begin{array}{l}\text { Choice in a Blind } \\
\text { Brand Experiment }\end{array}$ & $\begin{array}{l}\text { Home-made } \\
\text { Foreign-made }\end{array}$ & $\begin{array}{l}97(51 \mathrm{M}, 46 \mathrm{~F}) \\
103(49 \mathrm{M}, 54 \mathrm{~F})\end{array}$ & $\begin{array}{l}48.5 \\
51.5 \\
\end{array}$ \\
\hline & Total & & 200 & 100 \\
\hline
\end{tabular}

* Only the respondents with clear preference (see S/N 1) were used here.

** These mainly include Germany, Brazil, France, and China.

$* * *$ Six responses (out of 195 used from S/N 6) were nullified for multiple ticking.

$* * * *$ Two responses were nullified for multiple ticking. 
Table 4. Attitude Strength Score for Home and Foreign Shoes

\begin{tabular}{|l|l|l|l|}
\hline Shoe & Gross Attitude Strength Score & Net Questionnaire & $\begin{array}{l}\text { Average Attitude } \\
\text { Strength (As) }\end{array}$ \\
\hline Home & 66056 & $184^{*}$ & 359 \\
\hline Foreign & 7544 & $184^{*}$ & 41 \\
\hline
\end{tabular}

* For multiple ticking on this question, 16 responses were invalid.

NB: The attitude strength scores $\left(A_{S}\right)$ above are a relative measure, which were compared with the Best and Worst attitude scores for shoes. The Best attitude score tends to zero, showing that there is no deviation between the ideal rating and actual rating of shoes, such that $I_{i}-X_{i} \Rightarrow 0$. Therefore, for a shoe to have the best attitude strength score, it must be rated "excellent" (i.e. 5 points) on each attribute: same rating as the "ideal" score. Therefore, $\mathrm{A}_{\mathrm{S}}=\left[\mathrm{\sum W} i / 5-5 /\right]=0$.

On the other hand, a shoe's worst attitude strength index (AS) occurs when all shoe attributes are rated "poor" (i.e. 1 point) on each attribute, hence $\mathrm{AS}=[\mathrm{WWi} / 5-1 /]=400$.

\section{Appendix 2 Explanatory Methodology}

Measurement of Attitude Strength Using The Linear Compensatory Attitude (LCA) Model.

The LCA models hold that an individual's attitude toward an object is determined by his attitude towards the many salient attributes of the object (Churchill, 1976). The logic is that since beliefs about these attributes are evaluative in nature, the positive cognitions can lead (based on Consistency Theory) to positive attitude toward the object (Hawkins et. al 2001). These multiple evaluative attributes made the LCA model also to be referred to as the Multiattribute Attitude (MAA) model. The Wilkie-Pessemier Multiattribute model (Wilkie and Pessemier, 1973) was used here, thus:

$$
\mathrm{A}_{\mathrm{S}}=\sum_{i=1}^{n} w_{i} / I_{I}-X_{i h} /
$$

Where:

$\mathrm{A}_{\mathrm{S}}=$ Consumer attitude strength for shoes (home or foreign).

$\mathrm{W}_{\mathrm{i}}=$ The weight of the various shoes' attributes.

$\mathrm{I} i=$ Ideal rating of the different shoes on attribute $\mathrm{i}$.

$\mathrm{X} i=$ Respondent's belief (rating) about shoe's performance (home or foreign) on attribute i.

$i=$ Relevant shoe attributes.

$\mathrm{n}=$ Number of attributes being considered.

$/ \mathrm{I} i-\mathrm{X} i /=$ Absolute variance from the ideal shoe, of respondent's rating on each shoe attribute

(home or foreign).

The parameters are derived thus:

$\boldsymbol{n}$ and $\mathbf{W}$ : Table 3, S/N 8, is ranked and replicated for notations $n$ and $w$ here thus:

Table 5. Workings for $\mathrm{n}$ and $\mathrm{W}_{\mathrm{i}}$

\begin{tabular}{|l|l|l|}
\hline $\mathrm{n}$ & Attributes $i$ & Weight $\mathrm{W}_{i}(\%)$ \\
\hline 1 & Quality/durability & 54.5 \\
2 & Style/design & 18.7 \\
3 & Comfort & 9.6 \\
4 & Packaging & 7.6 \\
5 & Price & 5.6 \\
6 & Finishing & 2.5 \\
7 & Availability & 1.5 \\
\hline & Total & 100 \\
\hline
\end{tabular}


$\mathbf{I} \boldsymbol{i}$ and $\mathbf{X} \boldsymbol{i}$ : Ideal (I) and Actual ratings (X) are respectively got from the assumed "Excellent" rating and respondents' own ratings (see question 18 of the Questionnaire in Appendix 5).

The actual ratings $(\mathrm{X})$ ranged from "Poor" to "Excellent", with their corresponding points thus:

Table 6. Points for the Rating of Shoe Attributes

\begin{tabular}{|l|l|}
\hline Option & Point \\
\hline Poor & 1 \\
Fair & 2 \\
Good & 3 \\
Very good & 4 \\
Excellent & 5 \\
\hline
\end{tabular}

$/ \mathbf{I}_{\mathbf{i}}-\mathbf{X}_{\mathbf{i}} /$ : The absolute different between the ideal rating (Ii) and a respondents' rating (Xi) for shoes' attributes is a measure of the shoe's attitude favorability.

\section{Appendix 3 Test of Hypotheses 1 and 2 Using Kolmogorov - Smirnov (D) Test.}

This test is similar to chi-square, but differs, and is better, because it takes advantage of the ordinal nature of raw data. It was used here to test our preference hypotheses $\left(\mathrm{Ho}_{1}\right.$ and $\left.\mathrm{Ho}_{2}\right)$ where some ordering is prevalent.

It involves specifying the cumulative distribution function that would occur under the null hypothesis, and comparing that with the observed cumulative distribution function. The point at which the two functions show the maximum deviation is determined, and the value of this deviation is the test statistic (Churchill, 1976). The resultant Kolmogorov-Smirnov (D) Test statistic, which is equal to the absolute value of this maximum deviation, is compared with its corresponding critical value.

Where the test statistic is higher than the critical value, the null hypothesis is rejected. The null hypothesis is accepted however where the reverse is the case.

The D-test, utilized in hypotheses 1 and 2 can be summed thus:

$$
\begin{aligned}
& \mathrm{D} \\
& \begin{array}{l}
\alpha_{0.05} \\
=
\end{array} \\
& \text { Where: } \quad \mathrm{C} \quad=\text { Cumulative distribution function } \\
& \quad \mathrm{O} \quad \text { Observed cumulative distribution function } \\
& \mathrm{n} \quad=\text { Sample size } \\
& \alpha \quad=\text { Level of significance }
\end{aligned}
$$

\section{Hypothesis I}

$\mathrm{Ho}_{1:}$ There is no significant difference in the attitude strength between home-made and foreign shoes.

Table 7. Computation of Kolmogorov-Smirnov (D) Values for $\mathrm{H}_{1}$

\begin{tabular}{|l|l|l|l|l|l|}
\hline Attitude Subject & Attitude Score & $\begin{array}{l}\text { Observed } \\
\text { Proportion }\end{array}$ & $\begin{array}{l}\text { Observed } \\
\text { Cumulative } \\
\text { Proportion }(\mathrm{O})\end{array}$ & $\begin{array}{l}\text { Theoretical } \\
\text { Proportion }\end{array}$ & $\begin{array}{l}\text { Theoretical } \\
\text { Cumulative } \\
\text { Proportion }(\mathrm{C})\end{array}$ \\
\hline Home shoes & 359 & 0.90 & 0.90 & 0.50 & 0.50 \\
\hline Foreign & 41 & 0.10 & 1.00 & 0.50 & 1.00 \\
\hline
\end{tabular}

Maximum absolute deviation between observed cumulative proportion (0) and theoretical cumulative proportion (C) is:

$0.90-0.50=0.40$

$\therefore \mathrm{D}=0.40$

At $\alpha=0.05$, critical value for $D$ for large samples is:

$=\frac{1.98}{\sqrt{m}}=\frac{1.98}{\sqrt[3]{M}}=0.100$ 


\section{Hypothesis II}

$\mathrm{Ho}_{2}$ : There is no significant difference in preference pattern between home-made shoes and the foreign ones, in a Blind Brand Experiment.

All respondents (200) were asked to pick their choice from the two pairs (Home and Foreign) after filling the questionnaire. Countries of origin were concealed.

Still using the Kolmogorov-Smirnov (D) Test, and our tabulated results from the shoe choices made by all the respondents in the course of our Blind Brand Experiment (BBE) (See Table 3, S/N 9) we have:

Table 8. Computation of Kolmogorov-Smirnov (D) Values for $\mathrm{Ho}_{2}$

\begin{tabular}{|l|l|l|l|l|l|}
\hline Origin & BBE Pref. & Obs. Prop. & $\begin{array}{l}\text { Obs. Cum. } \\
\text { Prop. } \\
\text { (O) }\end{array}$ & $\begin{array}{l}\text { Theoretical } \\
\text { Prop }\end{array}$ & $\begin{array}{l}\text { Theoretical } \\
\text { Cum. Prop. } \\
\text { (C) }\end{array}$ \\
\hline Home & 97 & 0.49 & 0.49 & 0.50 & 0.50 \\
Foreign & 103 & 0.51 & 1.00 & 0.50 & 1.00 \\
\hline
\end{tabular}

$D$ value is at an absolute maximum where:

$0.94-0.50=0.01$

s. $\mathrm{D}$ calculated $=0.01$

At $\alpha=0.05$, critical value for $D$ for large samples

$=\frac{1.96}{\sqrt{2}}=\frac{1.96}{\sqrt{200}}=0.096$

\section{Appendix 4 Test of Hypothesis 3 Using Chi-Square Test}

Chi-square, denoted $\mathrm{X}_{2}$ is used here because of the nominal characteristics of the variables in Ho3.

It is given by (Chisnall, 1981):

$$
\mathrm{X}^{2}=\sum_{i=1}^{n} \frac{\left(\mathrm{O}_{\mathrm{i}}-\mathrm{E}_{\mathrm{i}}\right)^{2}}{\mathrm{E}}
$$

Where $\mathrm{Oi}=$ Observed frequency in the data.

$\mathrm{Ei}=$ Expected frequency in the data given the assumption of the null hypothesis.

\section{Hypothesis III}

Ho3: Consumption complex is not a significant determinant of shoes' brand choice.

Table 9. Chi-Square Test for Consumption Complex in a BBE

\begin{tabular}{|l|l|l|l|l|}
\hline Choices & Obs. Freq. $\left(\mathrm{O}_{\mathrm{i}}\right)$ & Exp. Freq. $\left(\mathrm{E}_{\mathrm{i}}\right)$ & $\left(\mathrm{O}_{\mathrm{i}}-\mathrm{E}_{\mathrm{i}}\right)$ & $\left(\mathrm{O}_{\mathrm{i}}-\mathrm{E}_{\mathrm{i}}\right)^{2}$ \\
\hline Right & 58 & 61 & -3 & 9 \\
Wrong & 84 & 61 & 23 & 529 \\
Undecided & 41 & 61 & -20 & 400 \\
\hline TOTAL & $183^{*}$ & & & 938 \\
\hline
\end{tabular}

*See Table 3, S/N 1

${ }^{\mathrm{s}}$ Chi-square (X2) value is 15.37 and the critical value at 0.05 level of significance and degree of freedom $(\mathrm{n}-1=$ 2) $=5.99$.

\section{Appendix 5 Consumer Questionnaire}

Dear Respondent,

This questionnaire is for an ongoing research on:

"Grappling With the Enduring Challenges of Consumption Complex Syndrome in Nigeria"

You are kindly requested to fill in the questionnaire as truthfully as possible. You are rest assured that your responses will be treated in utmost confidence, as even your name is not required. 
Instruction: Please tick $\square$ or fill in where appropriate.

\section{SECTION A}

1. In what age bracket do you belong?
a) $18-24$
b) $25-31$
c) $32-38$

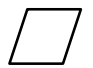
d) $39-45$

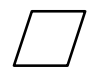

e) $46+$

2. Sex: a) Male

b) Female

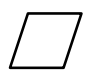

3. Occupation:

a) Application $\square$

d) Business person

f) Politician $\square$

b) Artisan

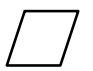

c) Civil servant

e) Professional (private sector)

g) Others (pls. specify)

4. What is your level of education so far?
a) None
b) Primary
$\square$
c) Secondary
d) Diploma
e) First Degree
$\square$ f) Post-graduate

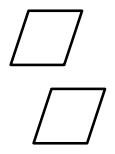

5. In what range is your total monthly income?
a).Less than $\mathrm{N} 6,000$
d) N35001 - N60000

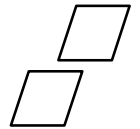
b) N6001 - N20,000
e) N60001 -N90000

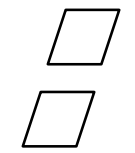

c) $\mathrm{N} 20001-\mathrm{N} 35000$.

f) $\mathrm{N} 90000+$

6. What is your marital Status?
a) Single
b) Married
$\square$
c) Separated/Divorced SECTION B

7. What kind of shoes do you usually prefer?
a) Homemade ones $\square$
b) Foreign ones
$\square$
c) Any one

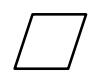

8. Why do you have this preference?

9. If you prefer foreign shoes, which country is your favorite shoe maker?

10. In the absence of your preferred kind of shoes, what would you normally do?
a) Settle for any other
b) Search further
$\square$
c) Forgo the purchase entirely

11. How many good enough pairs of shoes (excluding sandals/sneakers) do you presently have?
a) One
b) Two
$\square$ c) Three
d) Four
e) More than four

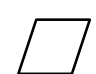

12. On the average, how regularly do you buy shoes?
a) Very regularly (monthly)
$\square$
c) Not too regularly (once in 5 months)
e) Very rarely (once in 12 months or more)
b) Regularly (once in 3 months)
d) Rarely (once in 8 months)

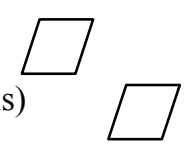

13. Can you clearly differentiate homemade shoes from foreign ones?
a) Yes
b) No
c) Sometimes

14. If yes above, what do you most look out for?
a) Label of origin
b) Packaging
e) Leather
f) Durability
c) Price $\square$
d) Finishing/Sleekness $\square$

15. Which of these do you put first in the purchase of shoes (pls. tick only one)
a) Price
b) Style/design
f) Finishing
c) Quality/Durability
e) Comfort
$\square$
$\square$
g) Availability
d) Packaging

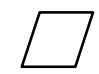

16. Do you think that homemade shoes are poorly patronized? 

a) Yes
b) $\mathrm{No}$
c) No idea

17. If yes, why is this so?

18. How would you rate shoes, using the following attributes?

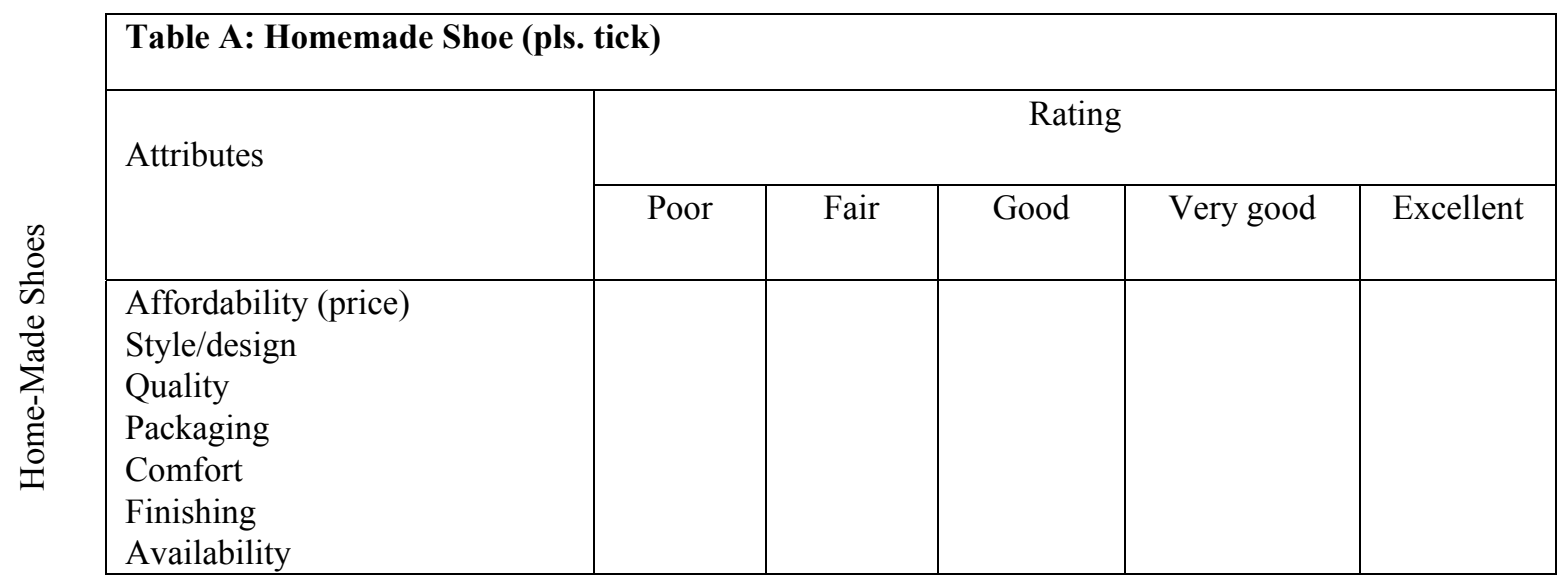

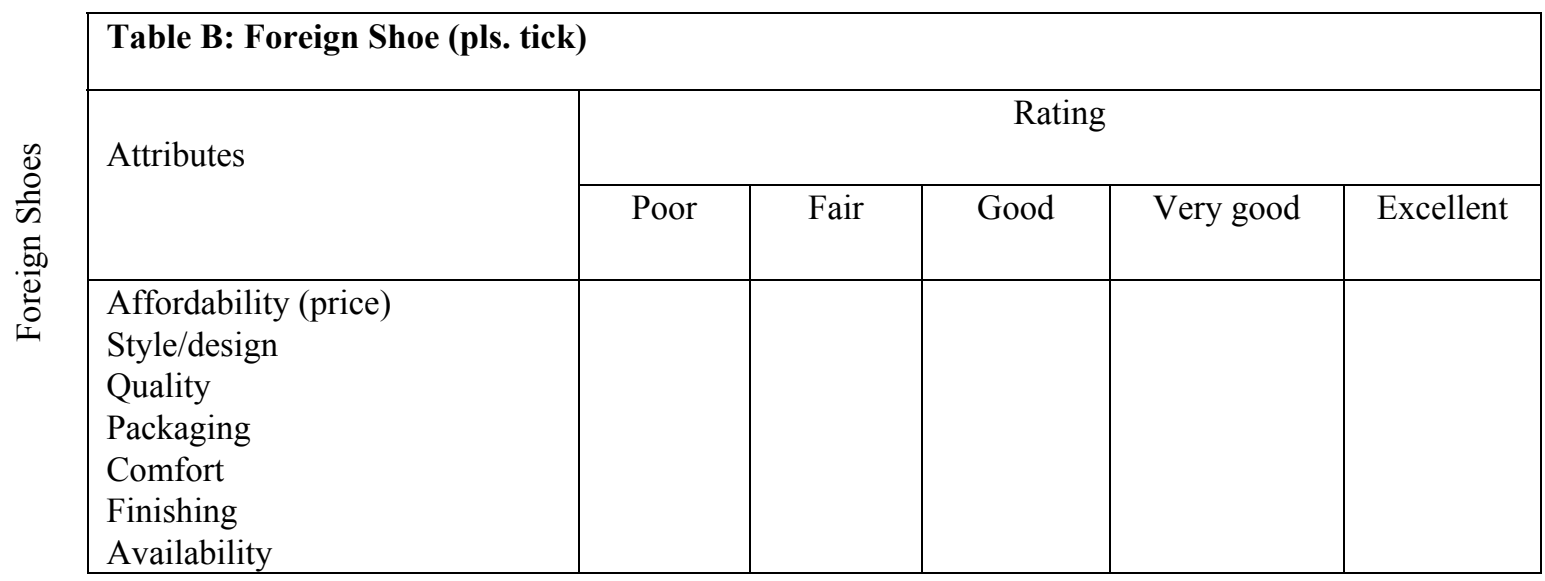




\section{Appendix 6 Proposed Model of CCS Prevalence and Management}

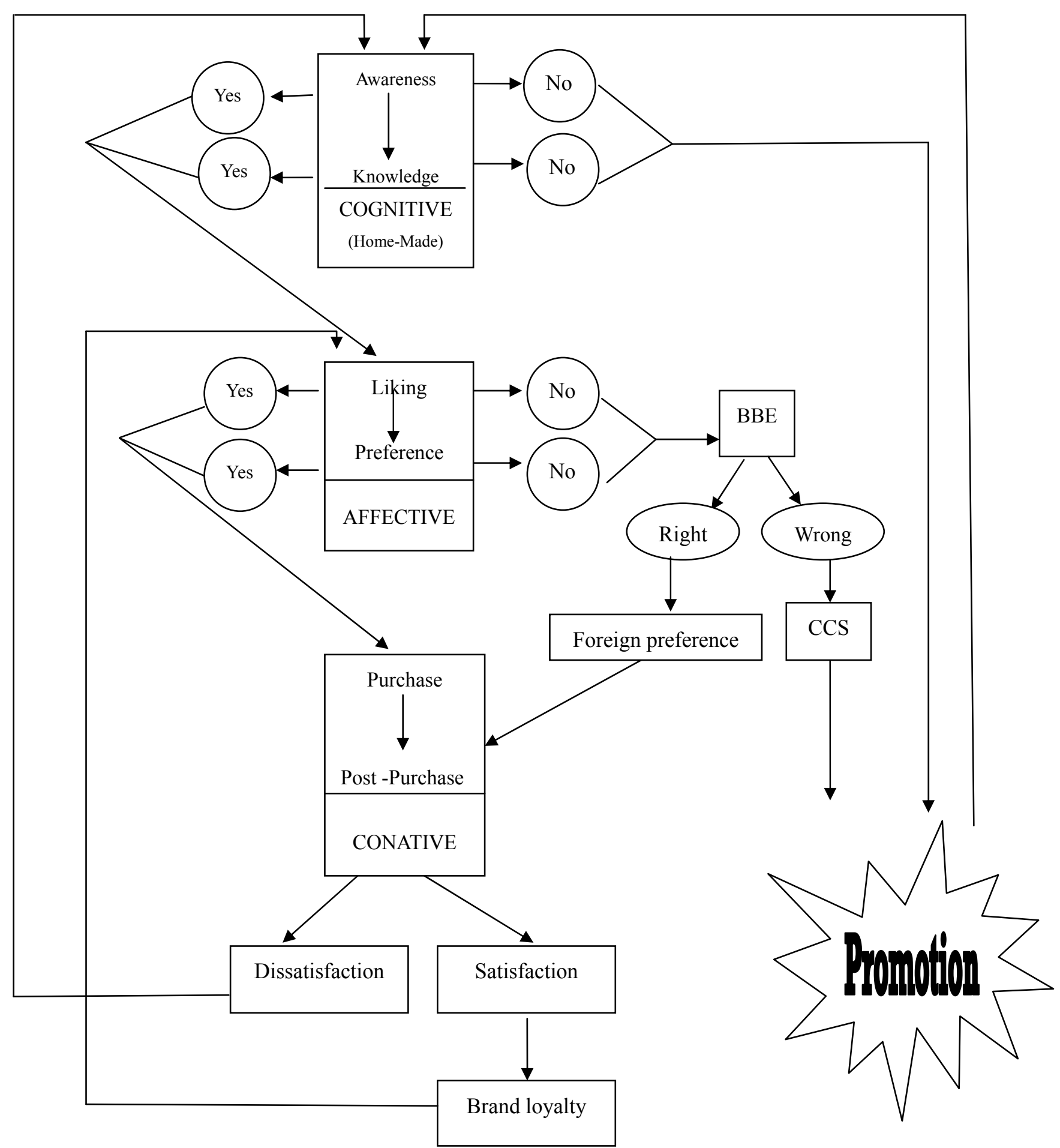




\section{Model's Explanatory Notes}

The spine of the model comprises the traditional three-component constituents of attitude: cognitive, affective and cognitive.

A consumer who is aware and consequently has knowledge of home-made products (shoes, in this case), will naturally move to the emotional phase (affective). Else, promotion could be used to consequently create the awareness/knowledge.

Again, if a consumer likes, and probably prefers home products, he will give it a trial (purchase). A consumer, who neither likes nor prefers domestic products, will be tested for conviction, through the Blind Brand Experiment (BBE), between home and foreign products.

Where the pro-foreign consumer clearly identifies the foreign product (shoes, in this case) from local ones in the $\mathrm{BBE}$, then he has a clear foreign preference. Otherwise, he has the Consumption Complex Syndrome (CCS), which again requires promotional efforts to re-orientate him appropriately.

A post-purchase evaluation occurs with the purchase of products (home or foreign). A satisfactory evaluation leads to brand loyalty. Dissatisfied consumers proceed to seek information (cognitive) on substitute brands of products (shoes). 